\title{
Transhipment simulators for training of ports' personnel
}

\author{
Alexandra HALLER ${ }^{1, a^{*} \text {, Lisa-Maria PUTZ }}{ }^{2, b}$ and Oliver SCHAUER ${ }^{3, c}$ \\ 1,2,3 University of Applied Sciences Upper Austria, Wehrgrabengasse 1-3, 4400 Steyr, Austria

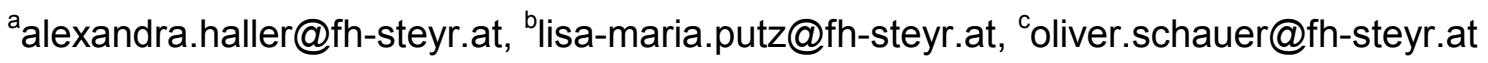

Keywords: transhipment, multimodal container terminals, port vehicles, simulator training

\begin{abstract}
As the transhipment of goods is a major cost factor within multimodal transport there is high potential in optimizing transhipment processes at container terminals and thus to reduce transportation costs. One aspect thereby is to improve efficiency of ports' personnel, optionally by using port vehicle simulators for training. The paper's aim is to identify the demand for port-transcending vehicle simulator training at container terminals in the Danube Region and to examine the feasibility of its practical implementation.

Results suggest high basic interest of container terminals in simulator training. Currently, simulators were mainly operated by crane and reach stacker (simulator) manufacturers. However, caused by the high technical and organizational expenses it is yet not possible or at least not profitable for container terminals itself to offer port-transcending simulator training.
\end{abstract}

\section{Introduction}

Transporting goods within multimodal container transports especially by using inland vessels is an environmentally friendly way of carrying goods [1]. However, organizing multimodal transport processes requires considerable logistical efforts [2]. One main aspect of planning multimodal transport processes is the transhipment of goods between the different modes of transport. As transhipping goods is very time-consuming and cost intensive there is high potential in optimizing transhipment processes at container terminals and hence to reduce transportation time and costs [3]. A key factor thereby is to train the ports' personnel. In fact, using simulation tools in training and education to gain practical experience in manoeuvring transhipment vehicles is one option to train ports' personnel [4]. Simulator training allows to make mistakes and to learn in a virtual and save environment without fearing to cause expenses through possible mistakes [5].

The aim of this paper is to identify the demand for port vehicle simulator training among the main container terminals along the Danube and based on that as well as on a validation of the industry to examine the feasibility of its practical implementation. Thus, a survey-based detailed requirement analysis as well as a validation of the industry on technical feasibility and profitability was made.

\section{Materials and experimental procedure}

In order to identify the demand to use port vehicle simulators within the Danube Region the first step was to determine a target group of potential users. Thus, based on an existing database [6] important container terminals along the Danube were selected as potential users.

Within the evaluated target group a survey about the operation of cranes and reach stackers was conducted. The goal of the survey was to:

- $\quad$ identify how training for operating port vehicles is currently performed within the ports,

- $\quad$ identify the demand for port vehicle simulator training and

- identify the interest of the interviewed partners in buying and operating a port vehicle simulator. 
For that reason the survey was structured into two main parts with the following questions:

Table 1 Survey questions

\begin{tabular}{|l|l|}
\hline Part 1: Current Situation at the Port & $\begin{array}{l}\text { Part 2: Demand and Requirements for } \\
\text { Simulator Training }\end{array}$ \\
\hline $\begin{array}{l}\text { 1. How many cranes and reach stackers are in } \\
\text { use at your terminal? }\end{array}$ & $\begin{array}{l}\text { 1. Would you as port operator send your } \\
\text { employees to simulator trainings? }\end{array}$ \\
\hline 2. How many people work with them? & $\begin{array}{l}\text { 2. How long would the accepted travelling } \\
\text { time be? }\end{array}$ \\
\hline $\begin{array}{l}\text { 3. How are employees currently trained to use } \\
\text { these transhipment vehicles? }\end{array}$ & $\begin{array}{l}\text { 3. How much would you pay for such } \\
\text { trainings? }\end{array}$ \\
\hline 4. By whom are they trained? & 4. Which competences should be trained? \\
\hline $\begin{array}{l}\text { 5. Are simulators in use for training at your } \\
\text { terminal? }\end{array}$ & $\begin{array}{l}\text { 5. Could you imagine buying and operating a } \\
\text { simulator yourself? }\end{array}$ \\
\hline
\end{tabular}

Based on the results of the survey, an implementation concept was developed to evaluate practical feasibility of offering port-transcending simulator training, operated by the container terminal itself. Afterwards, this concept was validated by the industry. In fact, transhipment service providers were questioned about different transhipment simulator types and their assessment concerning technical feasibility of port-transcending simulators operated by container terminals.

\section{Results and discussions}

\section{Survey evaluation}

As reach stackers and cranes are only in use at container terminals, mainly container operating ports along the Danube were questioned. In total 23 questionnaires from seven different countries Hungary, Croatia, Slovakia, Serbia, Romania, Bulgaria and Austria - were evaluated.

Current situation: Overall 342 people operate 259 cranes and 327 employees work with 203 reach stackers at the interviewed container terminals. According to the survey, the interview partners train their employees mainly at the companies reach stackers and cranes through colleagues or by specialized training companies. While simulator training is offered by crane and reach stacker (simulator) manufacturers itself, currently no crane and reach stacker simulators are in use for training at the questioned container terminals.

Demand and requirements for port vehicle simulator training: 13 of the 23 questioned interview partners stated basic interest in sending their employees to simulator training for reach stackers (six interview partners do not work with reach stackers). 15 out of 23 are basically interested on simulator training for cranes. This corresponds to a potential target group of 301 employees for reach stacker simulator training and 303 employees for crane simulator training.

However, two thirds of the participants made travel time related limitations. Only four ports would accept a journey of more than three hours for their employees to reach the simulator training. Hence, the accessibility and location of the potential simulator operators is essential. Additional limitations were made concerning the price for such trainings. In fact no container terminal would pay more than 500 Euros per person for the evaluated appropriate training duration of one day.

Buying and operating intentions: Two container terminals could imagine buying and operating a transhipment simulator to train employees as well as external people for money. At both terminals cranes are used to tranship goods. However, one of these ports does not use reach stackers.

In absence of current alternatives of potential training simulator operators within the ports, these two container terminals were analysed as potential training locations within the development of the 
implementation concept. Thus, hereinafter two potential locations for crane simulator trainings and one potential location for reach stacker simulator training were analysed.

\section{Implementation concept}

\section{Location and accessibility}

$2 / 3$ of the interview partners with a basic interest in sending its employees to specific simulator training would only accept a journey of maximum one hour or between one and three hours. Hence, it was of high importance to analyse the distance and travel time between the potential operating ports to the interview partners with a basic interest in sending its employees to simulator trainings.

The indicated travel times were calculated via Google Maps. As transhipment simulators are very complex and of big size, transporting them within the different ports would be very cost intense and not profitable. Therefore, this alternative was not further analysed.

In consideration of the maximum travel time, the interview partners would accept for their employees to reach the simulator training, the potential target group for simulator training changed as followed:

Table 2 Potential target group for crane and simulator training

\begin{tabular}{|l|l|l|}
\hline In total & Port 1 & Port 2 \\
\hline $\begin{array}{l}\text { Potential demand crane } \\
\text { simulator training }\end{array}$ & 63 employees & 79 employees \\
\hline $\begin{array}{l}\text { Potential demand reach } \\
\text { stacker simulator training }\end{array}$ & $-^{*}$ & 37 employees \\
\hline
\end{tabular}

*no reach stackers in use at Port 1

\section{Technical feasibility}

As there is an extreme variety of different models and equipment of transhipment simulators, the first important step within this phase was to get an overview of the different simulator types. Therefore a desktop research was conducted to identify relevant transhipment service providers. Results show different types of simulator manufacturers. The companies either offer transhipment simulators in addition to traditional cranes or reach stackers as a training facility, or they are specialised in producing different types of simulators and offer simulator training on different vehicles itself. The transhipment service providers were contacted via email and/or by telephone.

Research suggests that all high-quality simulators offered are individually customized to meet the clients' needs. There is a wide variety of types and brands of equipment simulated as well as of different motion platforms. In fact, hardware customizations, to meet specific brand requirements, software customizations, to meet specific demands, as well as a lot of different functions are required. Transhipment vehicle simulators are based on complex computer systems. These systems exactly reproduce all movements of transhipment vehicles in $3 \mathrm{D}$ and real-time. To create a realistic training environment where employees can be trained appropriate, it is important to operate in a cockpit where the real hardware utilised at the ports is used. Monitors and surround systems simulate the typical environment of container terminals $[7,8]$.

Taking research into account it has to be separated between:

- simulator training for new employees with no experience in operating a crane or reach stacker, and

- advanced simulator training for existing employees to optimize their skills.

Simulator training for new employees: For an initial training for people without experience in operating cranes or reach stackers it would be possible to use a basic transhipment simulator. Thus, new employees would gain first practical experience on how to generally operate cranes or reach stackers and get familiar with the basic functions. Therefore, no specific port environment as well as no exact hardware system is needed. But as the operation of cranes and reach stackers varies between the different types of cranes and reach stackers and as the employees have to get familiar 
with the port area, building on the basic simulator training, further training would be necessary. The acquisition costs for basic transhipment simulators start at about 12,000 Euros.

Advanced simulator training: To raise additional knowledge on how to operate cranes or reach stackers, so that transhipment processes can be optimized, much more complex and individually customized transhipment simulators would be required. To achieve this goal, the transhipment simulators have to be equipped with the actual hardware in conformity with the type and brand of cranes or reach stackers used at the different ports. Additionally the exact port environment has to be simulated and the training has to be adapted to the exact transhipment processes. As all these adaptations are needed to offer advanced simulator training, research suggests that it is not practical to use such advanced transhipment simulators at different ports. The costs of acquisition for such advanced and customized simulators are in the five-digit range. For that reason offering port-transcending advanced simulator training, operated by container terminals, is technically not possible yet caused by the different types of cranes and reach stackers used within the container terminals as well as the different port environment $[7,8]$.

\section{Profitability}

To analyse profitability, the number of potential users of such basic simulator training was evaluated. As a first step the number of people working on cranes and reach stackers at container terminals with basic interest in sending them to training was evaluated. In a second step travel time related limitations were taken into account. As basic simulator training is only relevant for people without experience, the potential target group had to be reduced to new employees. Assuming to an EU-wide fluctuation rate of about 18\% [9] the potential target group for cranes and reach stackers has to be reduced as follows:

Table 3 Potential target group for basic crane and simulator training

\begin{tabular}{|l|l|l|}
\hline In total & Port 1 & Port 2 \\
\hline $\begin{array}{l}\text { Potential demand basic } \\
\text { crane simulator training }\end{array}$ & $11-12$ employees / year & $14-15$ employees / year \\
\hline $\begin{array}{l}\text { Potential demand basic reach } \\
\text { stacker simulator training }\end{array}$ & $-^{*}$ & $6-7$ employees / year \\
\hline
\end{tabular}

As no port would pay more than 500 Euros per day and an average training duration of one day was evaluated the calculation would be as followed:

Table 4 Maximum earnings for basic crane and reach stacker training

\begin{tabular}{|l|l|l|}
\hline \multicolumn{2}{|l|}{$\begin{array}{l}\text { Maximum earnings basic } \\
\text { crane simulator training }\end{array}$} & $5,500-6,000 € /$ year \\
\hline $\begin{array}{l}\text { Maximum earnings basic reach } \\
\text { stacker simulator training }\end{array}$ & $-^{*}$ & $7,000-7,500 € /$ year \\
no reach stackers in use at Port 1 & $3,000-3,500 € /$ year \\
\hline
\end{tabular}

As extra training would nonetheless be necessary, the demand will probably decrease additionally.

Data evaluation suggests that offering port-transcending basic simulator training would yet not be profitable for the two potential operators. Comparing the maximum earnings above with the acquisition costs of about 12,000 Euros for a basic transhipment simulator and taking additional trainer and maintenance costs into account, the operating container terminals would not be able to even cover the costs. 


\section{Conclusions}

The study suggests that there is basic interest on simulator training for cranes and reach stackers within ports. However, the interview partners made strong limitations concerning price and accessibility of port-transcending simulator training since training requirements were also sufficiently covered by colleagues and training companies such as crane and reach stacker (simulator) manufacturers.

Regarding technical and economic feasibility, offering advanced port-transcending simulator training, operated by container terminals itself, is technically not possible yet. Offering basic port-transcending simulator training in contrast is possible in principle. However, in comparison to the maximum earnings with the acquisition costs of at least 12,000 Euros for a basic transhipment simulator and taking additional trainer and maintenance costs into account, it is currently not profitable or rather even cost covering for the potential operating container terminals.

This specific result is in line with the overall conclusion that using simulators for training is largely recognized and accepted within the educational sector but caused by high technical and economic efforts often not feasible or at least not profitable yet.

\section{References}

[1] European Commission, WHITE PAPER Roadmap to a Single European Transport Area Towards a competitive and resource efficient transport system, available at: http://eurlex.europa.eu/legal-content/EN/ALL/?uri=CELEX:52011DC0144, accessed: 2014-03-26.

[2] M. Gronalt, L. Höfler, D. Humpl, A. Käfer, H. Peherstorfer, M. Posset, H. Pripfl, F. Starkl, Handbuch Intermodaler Verkehr, Shaker Verlag, 978-3-8322-9899-9, Vienna, 2011.

[3] A. Rendl, M. Prandstetter, Constraint Models for the Container Pre-Marshaling Problem, available at: http://andrearendl.com/modref2013.pdf. accessed: 2014-06-30.

[4] A. Avramenko, Enhancing students' employability through business simulation, Education + Training, Vol. 54, No. 5, 2012, p. 355-367, 0040-0912, UK.

[5] L. Vos, R. Brennan, Marketing simulation games: Student and lecturer perspectives. Marketing intelligence and planning, Vol. 28 Iss: 7, pp. 882-897, 2010.

[6] viadonau, Danube ports, available at: http://www.danubeports.info/index.php, accessed: 201406-30.

[7] Liebherr: LiSIM: BOS 4200 - Liebherr Offshore Crane Simulator, available at: http://www.google.at/url?sa=t\&rct=j\&q=\&esrc=s\&source=web\&cd=2\&ved=0CDIQFjAB\&url=http $\% 3 \mathrm{~A} \% 2 \mathrm{~F} \% 2 \mathrm{Fwww}$. lisim.liebherr.com $\% 2 \mathrm{Fen}-$

GB\%2F143346.wfw\%3Ffile\%3D \%252FCMS\%252Fdownloads\%252FLiSIM_BOS4200.pdf\&ei= yKuWU5XBFNDn7Aaw8oFI\&usg=AFQjCNGwwPcZ1QsL9mTcxKktWza9oVFelQ\&bvm=bv.684 45247,d.ZGU, accessed: 2014-06-30.

[8] Liebherr: LiSIM: STS - RTG Crane Simulator, available at: http://www.google.at/url? sa=t\&rct=j\&q=\&esrc=s\&source=web\&cd=1\&ved=0CDUQFjAA\&url=htt $\mathrm{p} \% 3 \mathrm{~A} \% 2 \mathrm{~F} \% 2 \mathrm{Fwww}$. lisim.liebherr.com\%2Fen-

GB\%2F143346.wfw\%3Ffile\%3D \%252FCMS\%252Fdownloads\%252FLiSIM_STS__RTG.pdf\&ei=26yWU87YAqKI7AaP0oHABg\&usg=AFQjCNHwZ8wdYoIaMGjVyC7ZyHLtlVE NIw\&bvm=bv.68445247,d.ZGU, accessed: 2014-06-30.

[9] hay group: Sind Ihre Talente bereit zum Abflug?, available at: http://atrium.haygroup.com/downloads/marketingps/de/Sind\%20Ihre\%20Talente\%20bereit\%20zum \%20Abflug_executive_summary.pdf, accessed: 2014-06-30. 